\title{
A GLOSSARY OF SKֵWXXWÚ7MESH SNÍCHIM REVITALIZATION: THE WORK OF ADULT INDIGENOUS LANGUAGE EDUCATION
}

\author{
Nicki Benson 1 \\ University of Victoria \\ Khelsilem \\ Skw $\underline{x} w u ́ 7 m e s h-K w a k w \underline{a} k \underline{a}{ }^{\prime}$ wakw educator
}

\begin{abstract}
In determining if and how successful practices in Indigenous language revitalization (ILR) can be replicated or adapted, it is critical to understand the context in which such practices have shown success. In this article, the authors experiment with a glossary approach (Hurren, 2014, 2018; Tuck \& Ree, 2013) to present the context of Skwwwú7mesh Sníchim, a language that has seen a dramatic increase in the number of speakers since the introduction of an adult immersion program in 2016. Through a list of selected key words and phrases related to Skwxwú7mesh language revitalization, the authors explore this effort in a creative and thought-provoking way. As the story of Skwxwú7mesh Sníchim emerges through the words, both common and unique elements of the context are revealed, inviting readers to reflect on connections and possibilities in ILR. While the glossary provides insights for researchers interested in learning about and from the case of Skwxwú7mesh Sníchim, it is also an example of how scholarly writing can be done in an interesting and accessible way to reach a wider audience. The glossary is not a prescriptive list of definitions, but rather a creative twist on qualitative writing that tells a story of ILR from a particular perspective at a particular time. This article provides insights into this case and hopes to prompt reflection for others engaged in this work.
\end{abstract}

Keywords: Indigenous languages, language revitalization, adult language learning, immersion education, qualitative writing

Citation: Benson, N. \& Khelsilem. (2021). A glossary of Skwwxwú7mesh language revitalization: The work of adult Indigenous language education. WINHEC: International Journal of Indigenous Education Scholarship, 16(1), pp. 142-178. http://dx.doi.org/10.18357/wj1202120285. Special Issue on Indigenous Language Revitalization: Innovation, Reflection and Future Directions, Guest Co-Editors Drs. Onowa McIvor and Kari A. B. Chew.

${ }^{1}$ Correspondence: Nicki Benson, University of Victoria, nickibenson@uvic.ca 


\section{Introduction}

This glossary presents a partial list of words and phrases related to the revitalization of Skwwxwú7mesh Sníchim, the Squamish language. It has been compiled with the intention to help familiarize others with the field of Indigenous language revitalization (ILR), the specific issues facing Sknwxwú7mesh Sníchim, and the innovative approaches the Sknwxwútmesh people are taking to protect and strengthen their language. Heeding Richardson and St. Pierre's (2018) call for qualitative research writing that is less "boring," we experiment with a glossary approach to present this information in a creative way that is both reader-friendly and academic. The result is a snapshot of Skwwwú7mesh language revitalization at a particular moment, with adult learning at its core, told from the authors' perspectives. It is intended to be revised collaboratively as the context changes and the story evolves in the years to come.

\section{Sharing Stories of Indigenous Language Revitalization}

Language revitalization is a pressing priority for Indigenous Peoples. Attempts by colonial governments to eradicate Indigenous cultures and languages have been deliberate and pervasive (Pine \& Turin, 2017). Canada's colonial history saw centuries of violence, racism, and assimilation efforts by churches and governments that actively sought to eliminate Indigenous Peoples and cultures (Truth and Reconciliation Commission of Canada, 2015). The impact of this violent dispossession is evident in the low number of speakers of many Indigenous languages today and the continued marginalization faced by Indigenous Peoples in Canada and around the world. Despite these challenges, Indigenous Peoples have shown incredible resilience and a commitment to their cultures. They have been working to 
revitalize and strengthen their languages for decades, utilizing a wide range of innovative strategies (McIvor \& Anisman, 2018), often with extremely limited resources.

As Indigenous communities work tirelessly to create new speakers, they look to one another for strategies and support. McIvor (2015) has identified the need for more ILR success stories to be made available, in particular to inspire and motivate adult Indigenous language learners. In telling such stories, however, it is critical to share contextual information so that others seeking to learn from best practices can determine if and how these might be replicated or adapted to their own contexts.

The success story in focus here is adult learning of Skwwxwú7mesh Sníchim, an Indigenous language spoken by the original inhabitants of a territory on the west coast of what is now called Canada, which includes the watersheds of the Burrard Inlet, False Creek, English Bay, and Howe Sound (see Figure 1). In 2014 there were only seven remaining first language speakers of Skwwxú7mesh Sníchim (FPCC], 2014), and today, sadly, there are none. However, in 2016, the community organization Kwi Awt Stelmexw created a full-time adult immersion program for the language with assistance from Simon Fraser University. Before the Certificate in Skwxwú7mesh Language Proficiency (CSLP)² began, there were only a handful of learners who had reached an intermediate level or higher in Skwwwwú7mesh Sníchim. By spring 2020, the program had graduated over 50 new speakers at these levels.

\footnotetext{
2 When the certificate program began, it was offered through SFU's Certificate in First Nations Language Proficiency, subsequently renamed the Certificate in Indigenous Language Proficiency. This certificate is offered for several Indigenous languages. For clarity, this paper refers only to the Skwxwú7mesh Sníchim certificate and diploma programs, we have replaced the word Indigenous with Skwxwú7mesh in their titles.
} 
In addition, the Diploma in Skwwxwú7mesh Language Proficiency (DSLP) had been created and graduated its first cohort of 18 students. In this article, we share the story of these programs and Skwwxwú7mesh Sníchim revitalization with attention to factors in the broader educational, historical, and socio-political context.

\section{Figure 1}

Map of Communities with Squamish Language Learners \& Speakers

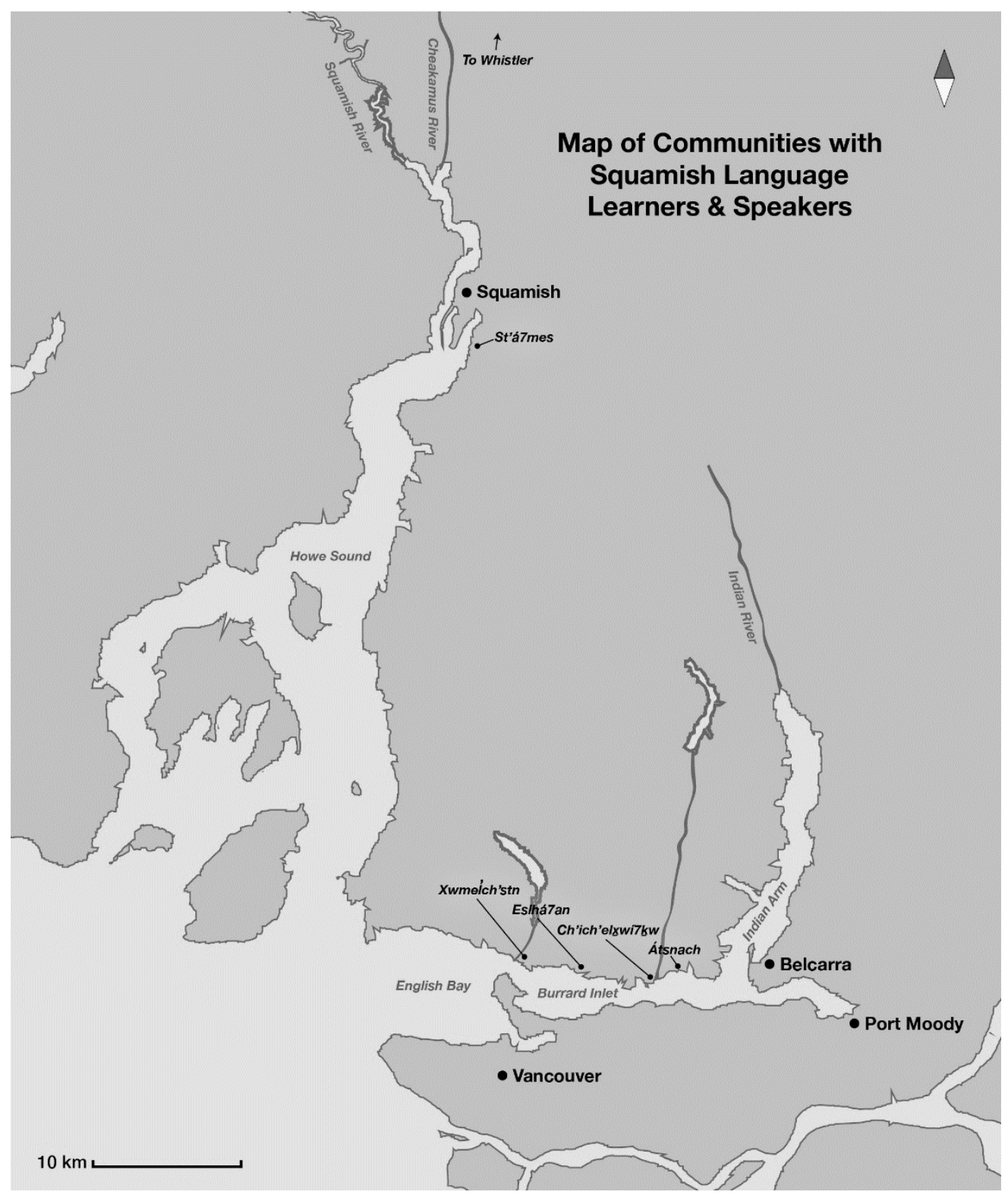

Note. Map designed by Khelsilem 


\section{A Glossary Approach to Qualitative Writing}

A glossary ordinarily comes after a text, to define and specify terms, to ensure legibility. Glossaries can help readers to pause and make sense of something cramped and tightly worded; readers move from the main text to the back, and forth again. In this case, the glossary appears without its host - perhaps because it has gone missing, or it has been buried alive, or because it is still being written. (Tuck \& Ree, 2013, p. 640)

A stand-alone glossary is an arts-based approach to qualitative writing, an example of creative nonfiction (Miller \& Paola, 2019). The aim of creative nonfiction is to present factual information in an accessible and interesting way (Caulley, 2008), expanding the potential to reach a wider audience than typical research papers. A stand-alone glossary is an example of what Miller and Paola (2019) call a "hermit crab essay," an essay written using the structure or "shell" of another writing form (p. 111). The stand-alone glossary has been used by Tuck and Ree $(2013)$ and Hurren $(2014,2018)$ to present literature and research findings. Written as pieces of creative nonfiction, stories emerge through the words and phrases in their glossaries, expanding the readers' awareness and understanding of the topic in question.

The glossary approach is both academic and artistic, particular and general, linear and circular. It is presented alphabetically but can be read in any order with no clear beginning or end as all the terms are interrelated. Many of these interrelations are indicated through cross-referencing, encouraging the reader to move through the glossary in a non-linear fashion. Tuck and Ree (2013) argue that such an approach violates "the terms of settler 
colonial knowledge which require the separation of the particular from the general, the hosted from the host, personal from the public, the foot(note) from the head(line), the place from the larger narrative of nation" (p. 640). They explain that their glossary does not aim to tell the complete story, but is a "fractal" (p. 640). In the block quote above, they also indicate how glossaries can be useful for telling stories that have been suppressed or those that are still emerging. Part of the story, then, is told in the gaps between words, the elements that are still missing. Hurren (2018) notes for her glossaries that "a complete compilation of words ... is not possible nor even desired" (p. 534). Their glossaries, and this one, do not aim to create a definitive product or final answer, but to shed light on a particular phenomenon from a particular angle at a particular time.

\section{Introduction to the First Edition of the Glossary}

This is the first iteration of the Glossary of Skwwxwú7mesh Language Revitalization. It is intended to be reviewed and expanded over the years. The words have been chosen subjectively based on the authors' perspectives and experiences. Khelsilem is a Skwwxwú7mesh-Kwakwaka'wakw language revitalization activist, language teacher, and the founder of the CSLP. Nicki is a non-Indigenous graduate student working with the Skwwxwú7mesh language community; she has worked with Khelsilem in the past, including providing administrative support for the creation of the CSLP.

We view the CSLP and DSLP, with their focus on adult immersion education, as the key to success in Skwwwú7mesh Sníchim revitalization in recent years. However, the story of these programs cannot be understood outside of the wider context. Some words selected for the 
glossary, therefore, speak to the context, such as the history of language devitalization, the work that came before the CSLP to ensure the language was passed on, and the relationship between the CSLP, DSLP, and other programs. Other words speak very specifically to the CSLP, its creation, contributors, and teaching methods. In some cases, the connections between entries are made explicit through cross-referencing. In others, we leave these connections open to interpretation. As all of the words are interconnected, we leave space for readers to move through them freely, rather than follow a prescribed narrative.

We have chosen to use English as the primary language for this glossary. This is intentional as we hope that it will be accessible to a wide audience, serving as a practical and informative resource. In some cases, we use Skwwxwú7mesh words as an educational element of the glossary and in others because the words are specific to the language or are official titles. Where there is a glossary entry about a Skwxwú7mesh person, we list them by their English name first with their Skwwxwú7mesh name in parentheses. Sknwxwú7mesh names are not held by only one individual, but are passed down within families. To include these entries by Skwwxwú7mesh name first, we would need to describe all the people with this name, as well as the meaning of the name, and not just the person we intend to discuss. In order to share the former information, we would need permission from various families and individuals. This would be very informative to include in a subsequent edition of the glossary, but due to both time and word constraints, it is not included here. Likewise, all Sknwxwú7mesh people mentioned elsewhere in the text are listed by their English names to maintain consistency. For a future iteration of the glossary, we will consult with individuals or families of deceased individuals about how they would prefer their names to appear. 
The glossary does not and cannot cover the complete body of literature in the field of ILR or the entire history of Skwxwú7mesh Sníchim revitalization, nor does it include the perspectives of all Skwwwú7mesh peoples who have been involved in these efforts. The glossary would be enhanced from input and collaborative development with additional members of the Skwxwú7mesh language community. Our intention is to review and update the glossary every five years through such a collaborative approach. It is hoped that this first iteration of the glossary will provide an introduction to Skwwwú7mesh language revitalization, and that readers will find connections, cause for reflection, and new understandings.

\section{Glossary}

\section{$\boldsymbol{A}$}

Adult learners learn differently than children and cannot be treated the same. While they have stronger cognitive ability to process complex grammar information (Grenoble \& Whaley, 2006), they require higher levels of motivation than children to sustain learning (Griffiths \& Soruc, 2018). Issues of identity and affiliation to the language affect adult learning (Muñoz \& Singleton, 2011) and the ongoing impacts of colonial trauma affect many adult Indigenous learners (Jenni et al., 2017). However, for severely threatened languages, education efforts must focus on effectively educating adults who can become teachers to future generations (see MISSING GENERATION).

Assessment is used by students and teachers to determine what has been learned. It is important for measuring progress, evaluating teaching practices, informing curriculum, and 
influencing policy. It is a growing area of interest in ILR, and practitioners are working to develop Indigenous-informed, learner-driven approaches to assessment for language programs (e.g., McIvor \& Jacobs, 2016). The CSLP and DSLP use Oral Proficiency Interviews based on the American Council on the Teaching of Foreign Languages (ACTFL) proficiency scales for assessing students' progress.

C

Community language classes are gatherings of language learners and teachers, usually without attachment to accreditation by an institution. They are often offered for adults or families who cannot regularly participate in classes taught at schools or other institutions. Skwwxwú7mesh Sníchim community classes have been taught in various iterations since the 1960s by different language speakers in various communities. The classes have typically been offered 1-2 nights per week for 2-4 hours per class (see TEACHERS).

Core language classes is the term used by the British Columbia Ministry of Education to describe language classes that are taught as a subject in $\mathrm{K}-12$ public and private schools. These classes are typically no more than 90 minutes per week. Core Sǩwxwú7mesh Sníchim classes have been offered in schools on Skwxwwú7mesh territory since the 1980s and are entirely funded from the Squamish Nation's own source revenue (see SKWXWÚ7MESH TERRITORY; TEACHERS). 
Elders are not defined by their age, but rather by their wisdom and the respect that they have earned from their community who value them as teachers and spiritual guides. Often, they are Indigenous language speakers, or they have advanced proficiency, and their guidance is crucial for informing revitalization efforts (see SEVEN; TA NEXWNÍWN TA A ÍMATS).

Evan Gardner is the original developer of the Where Are Your Keys (WAYK) system for language teaching and learning. Khelsilem reached out to Evan in 2007 and started learning WAYK over Skype. In 2009, Khelsilem began teaching community classes for Skֵwxwú7mesh Sníchim using WAYK and, as the Language Revitalization Advisor with Tsleil-Waututh Nation (TWN), he worked with Evan and the WAYK team to develop their language programs. Where Are Your Keys has always been used to teach Skwwxwú7mesh Sníchim in the CSLP and is used for courses in the DSLP. Evan continues to work as a language consultant for TWN and Skwwxwú7mesh Sníchim, providing support for the CSLP and DSLP (see THE YELLOW HOUSE; WHERE ARE YOUR KEYS).

\section{$\boldsymbol{F}$}

First Nation is an Indigenous government with recognition in Canada, either through their inherent self-determination or status as an Indian Band with meaning under the Indian Act. The Squamish Nation and the Tsleil-Waututh Nation are examples of First Nations (see THE INDIAN ACT; INDIGENOUS PEOPLES; THE SQUAMISH NATION; TSLEIL-WAUTUTH NATION). 
First Peoples' Cultural Council (FPCC) is a crown corporation in British Columbia whose mandate is to support Indigenous language, arts, and culture. FPCC has funded numerous language revitalization programs for Skwwxwú7mesh Sníchim, including the BC Language Initiative, the Aboriginal Language Initiative, Mentor-Apprentice Programs, the Skwwxwú7mesh Language Nest, and Community Language Planning. First Peoples' Cultural Council has funded initiatives with the Squamish Nation, Tsleil-Waututh Nation, and Kwi Awt Stelmexw (see KWI AWT STELMEXW; LANGUAGE NESTS; MENTOR-APPRENTICE PROGRAM).

Fluency is the term most people use to describe speaking well. However, it is a contested term that is hard to define. Many language communities have turned their focus instead to language proficiency, recognizing that one can be skilled, or proficient, in some aspects of the language and not others (see PROFICIENCY; $\underline{\text { SEVEN). }}$

\section{I}

Immersion is when the target language is used as the exclusive medium of instruction. Being fully immersed in a language is the best way to learn (Grenoble \& Whaley, 2006; McIvor \& Anisman, 2018; Tedick et al., 2011). The CSLP is the first full-time immersion program for Skwwxwú7mesh Sníchim at any level. English is used only in the first six weeks to explain the teaching methods and establish classroom protocols. During the first two years of the program, English was not used otherwise. In the Yellow House, where the program operated subsequently, there was an "English room" which students could enter to discuss pressing 
matters in English if needed (see THE CERTIFICATE IN SKWXWÚ7MESH LANGUAGE PROFICIENCY; THE YELLOW HOUSE).

Indigenous language education programs are different from programs for dominant languages. Indigenous languages are grammatically different from dominant languages, and cannot be taught in the same sequence (Kell, 2014). There are often very few resources available for Indigenous languages, such as written materials, curriculum documents, or trained teachers (Hinton, 2011). Most importantly, the motivations of Indigenous learners are different from those of other language learners; they are not learning the language for travel or employment opportunities, but for reasons that connect to their rights and identity (McCarty, 2012) (see POLYSYNTHETIC LANGUAGES; RECLAMATION).

Indigenous language revitalization (ILR), also called language regeneration, language revival, language reclamation, and reversing language shift, among other terms, refers to efforts by Indigenous Peoples and others to strengthen the use of Indigenous languages. While producing new speakers is often a primary goal, ILR is part of wider community building efforts and "a larger fight for Indigenous cultural survival, human rights, and self determination" (McCarty, 2012, p. 1172) (see IOSHUA FISHMAN, RECLAMATION).

Indigenous Peoples are defined by Indigenous Peoples we work with as the original inhabitants of a territory that has been colonized. In Canada, Indigenous Peoples are often called Aboriginal, a legal term representing three distinct groups: Inuit, Métis, and First Nations. Skwwwú7mesh peoples are First Nations, the original inhabitants of a territory on 
the west coast of what is now Canada (see FIRST NATION; SKWXWÚ7MESH ÚXWUMIXW; SӘĹLLWӘTAE).

$J$

Joshua Fishman (2001; 1991) studied the causes of what he calls language shift, the movement away from using one language in favour of another. Through case studies of languages all over the world, Fishman identified the causes of language loss and developed guidelines for language planning and reversing language shift. Fishman's Graded Intergenerational Disruption Scale provides a model for understanding language endangerment or development and strategies to employ depending on the language's status. It demonstrates that for languages where the only fluent speakers are elderly and the language is not being transmitted to children in the home, revitalization efforts must focus on educating adults who can become the teachers to future generations. This model inspired the strategy employed by Khelsilem and is the reason for focusing on adult immersion programs over programs for children (see MISSING GENERATION; $\underline{\text { SEVEN). }}$

\section{$\boldsymbol{K}$}

Kanien'kehá:ka are called Mohawk in English and are Indigenous Peoples who reside primarily in present-day Quebec, Ontario, and New York State. Their language is a polysynthetic language called Kanien'kéha or Mohawk. The Kanien'kehá:ka communities of Kahnawà:ke and Ohswé:ken developed full-time adult immersion programs that served as inspiration for the CSLP. Khelsilem visited these communities and received support from Owennatékha (Brian Maracle) and Onekiyóhstha (Audrey Maracle) who had established the 
Onkwawén:na Kentyóhkwa adult immersion school in Ohswé:ken in 1998 (see POLYSYNTHETIC LANGUAGE).

Kwi Awt Stelmexw (KAS) is the name of a non-profit organization founded by Khelsilem to strengthen Skwwxwú7mesh language and culture. Kwi Awt Stelmexw is a phrase that roughly translates to "the coming after people," which could refer to either ancestors or future generations, reminding us that we are the ancestors to the unborn children yet to come (Kwi Awt Stelmexw, 2019). Nicki worked for the organization from 2015-2017.

In 2016, KAS approached Simon Fraser University about using their Certificate in Indigenous Language Proficiency to run a full-time immersion program for Skwwxwú7mesh Sníchim. This would allow students to access education funding from their Nations and earn university credits while learning their language. This is how the CSLP began. Kwi Awt Stelmxw continues to provide funding for the CSLP and DSLP to hire language apprentices, assistants, and mentors (see TEACHERS; THE CERTIFICATE IN SKWXWÚ7MESH LANGUAGE PROFICIENCY).

$\boldsymbol{L}$

Language champions are those who dedicate their lives to revitalizing and teaching their languages. Often, it is a handful of highly dedicated individuals that lead the way for ILR in their communities, demonstrating incredible strength, resilience, and innovation despite personal, social, and political barriers (see TA NEXWNÍẂN TA A ÍMATS; TEACHERS). 
Language Nests are immersion daycares or preschools which have been the key to success for Māori and Hawaiian language revitalization (Hinton, 2011). In 2018, a language nest was created by Squamish Nation's Language and Cultural Affairs Department for children ages 0-4 and their parents. It is next to Xwmélch'stn' Estimiaw'txw, and the staff are graduates from various Skֵwxwú7mesh Sníchim programs (see XWMÉLCH'STN' ESTIMIAW’TWX).

Linguists have a complicated history with Indigenous communities. While historically many non-Indigenous linguists have treated Indigenous communities as data sources for their own academic interests, their language documentation work has become invaluable in many language revitalization efforts. More recently, linguists are changing the way they work with Indigenous communities and are becoming more collaborative in their approaches (e.g., Czaykowska-Higgins, 2009; Leonard \& Haynes, 2010; Rice, 2009). In addition, more Indigenous people are choosing to become linguists (Gerdts, 2017).

Beginning with Franz Boas in the 1880s, various linguists included Skwwxwú7mesh word lists in their work. In the 1950s Aert Kuipers was the first to compile a complete reference grammar for Skwwxwú7mesh Sníchim, working with Isaac and Lizzie Jacob, Alex and Mary Peters, and Louis Miranda (Squamish Nation Education Department, 2011, p. xi). Randy Bouchard and Dorothy Kennedy then worked extensively with the language and developed the orthography with Louis Miranda that is used today. Documentation by these and other linguists laid the foundation for Skwxwú7mesh curriculum materials used in schools (BakerWilliams, 2006). 
Since the 1990s, Skwwxwú7mesh Sníchim documentation has been led by Skwwxwú7mesh people, including Skwwxwú7mesh linguist Peter Jacobs and the Squamish Nation Education Department, as well as collaborative work with non-Indigenous linguists from local universities (see LOSHUA FISHMAN; LOUIS MIRANDA; PETER JACOBS; TA NEXWNÍẂN TA A ÍMATS).

Louis Miranda (Sxáaltxww Siýámu), known to many as Uncle Louis, "inspired generations as a champion of the Squamish language and culture" (University of British Columbia, n.d., para. 2). He worked closely with Aert Kuipers in the 1960s to write the first comprehensive grammar for Skwwxwú7mesh Sníchim, and his own documentation work included writing hundreds of pages of lessons, stories, and legends in the language. He was one of the first Skwwxwú7mesh language teachers in the 1960s, and he taught well into his 90s. He also held the title as a siýám (hereditary leader) for 53 years (see LANGUAGE CHAMPIONS).

\section{$M$}

Māori are the Indigenous People of Aotearoa (New Zealand). The Māori People's movement for language revitalization has served as an inspiration for many Indigenous communities around the world, including the Skwwxwú7mesh people. Māori language champions, followed by those in Hawai'i, were among the first to implement many successful ILR strategies including language nests, bilingual schools, and adult immersion programs (King, 2001).

Medium of instruction is the language used to teach a given subject. In Canada, nearly all public schools use English or French as the medium of instruction. Provinces and territories 
in Canada have varied policies regarding the use of other languages as the medium of instruction in bilingual and immersion programs. The CSLP and most courses in the DSLP use Sknwxwú7mesh Sníchim as the medium of instruction.

Mentor-Apprentice Program (MAP) is a program structure developed by Leanne Hinton and Indigenous language activists in California to facilitate language acquisition by apprentice learners with mentor speakers through immersion-based activities (Hinton, 1994). The First Peoples' Cultural Council funds MAPs wherein "the mentor and apprentice spend 300 hours per year together doing everyday activities using the language at all times" (FPCC, 2019, para. 2). MAPs have been used by Sknwxwú7mesh language learners, including Khelsilem. He conducted a one-year MAP with Vanessa Campbell, and his proficiency advancement through this experience formed the basis for the development of the CSLP (see FIRST PEOPLES' CULTURAL COUNCIL; TEACHERS).

Missing generation is a term increasingly used to describe adult Indigenous language learners who "hold great potential to contribute to the revival of Indigenous languages by acting as the middle ground between Elders, children, and youth within their communities" (Jenni et al., 2017, p. 25). Languages thrive when children are being raised in the language, but this is only possible if child-bearing adults are speakers (Fishman, 1991). In communities with few or no remaining first language speakers, ILR efforts must focus on creating a critical mass of adult speakers who can teach their own children as well as other children and adults in the community. 


\section{$\boldsymbol{O}$}

Orthography is the writing system used for a given language. Skwwxwú7mesh Sníchim was an oral language with no writing system before colonization. Various anthropologists and linguists used different systems in their documentation of the language. In the 1960s, Randy Bouchard and Dorothy Kennedy worked with Louis Miranda to develop the orthography for Skwwxwú7mesh Sníchim which was later adopted as the official writing system. Notably, the orthography uses the numeral 7 to represent the glottal stop, as it was designed for ease of use on conventional typewriters which did not include the symbol / $/$.

\section{$\boldsymbol{P}$}

Peter Jacobs (T'naxwwtn) is a Skֵwxwú7mesh and Kwaguł linguist who has been working tirelessly for the language for several decades. He worked for 20 years in the Squamish Nation Education Department, served as editor-in-chief on the first Squamish-English dictionary, and is now a professor at Simon Fraser University. He teaches in the CSLP and spearheaded the creation of the DSLP (see LANGUAGE CHAMPIONS; LINGUISTS; THE DIPLOMA IN SKWXWÚ7MESH LANGUAGE PROFICIENCY).

Polysynthetic language: A language in which words are made up of many morphemes, or units of meaning. In such languages, single words can contain as much information as whole sentences in more "isolating" languages such as English (Kell, 2014). Approaches to teaching polysynthetic languages are different from teaching isolating languages, as they must be taught in a sequence that allows students to move from basic to more complex word 
construction (Kell, 2014) while also fostering an appreciation for the rich meaning and metaphor each individual word might carry (Rosborough et al., 2017).

Proficiency is a term used to describe language abilities with varied definitions. It is often distinguished from fluency in that it refers to one's ability to use and understand language even if they cannot always speak fast or fluidly. Khelsilem was introduced to proficiency through Where Are Your Keys, which has defined proficiency as the ability to produce and comprehend accurate language at increasing levels of complexity. He adapted the American Council Teaching of Foreign Language's Oral Proficiency Guidelines for use in the CSLP, and these continue to be updated for use in the DSLP (see ASSESSMENT; FLUENCY; WHERE ARE YOUR KEYS).

\section{$\boldsymbol{R}$}

Reclamation is a term used in ILR in two different ways: either to refer to revitalization of a language that no longer has any first language speakers or to recognize that ILR is not only about language, but is part of a wider anticolonial resistance movement, tied to Indigenous rights, self-determination, and community building (Hinton et al., 2018). Both definitions of the term apply in the case of Skwwwú7mesh Sníchim (see $\underline{\text { SEVEN)}) . ~}$

Residential Schools were boarding schools that Indigenous children in Canada were forced to attend from the early 1900s to 1950s and later in some cases. The primary purpose was to assimilate Indigenous children into Euro-Canadian and Christian culture. The education they received at these schools was very poor, and former students have described horrific 
cases of physical, emotional, and sexual abuse (Truth and Reconciliation Commission of Canada, 2015). The children were ridiculed and punished for practising their culture or speaking their languages. As the "intent was to eradicate all aspects of Aboriginal culture in these young people and interrupt its transmission from one generation to the next, the residential school system is commonly considered a form of cultural genocide" (Indigenous Foundations, 2009, para. 3). Residential schools are recognized as the primary cause of Indigenous language loss in Canada.

St. Paul's Indian Residential School in North Vancouver housed Skwwxwú7mesh children from 1899 to 1958, and others were sent to schools in more distant communities (Baker-Williams, 2006). Many of these children spoke Sknwxwú7mesh Sníchim at home in early life but were forced to stop using it at school. Even if they retained knowledge of the language, many were ashamed to continue using it or did not pass it on to their children for fear of repercussion (see SAFE LEARNING ENVIRONMENTS; SETTLER COLONIALISM; SEVEN; THE INDIAN ACT; THE TRUTH AND RECONCILIATION COMMISSION OF CANADA).

$S$

Safe learning environments are comfortable, welcoming, and guided by compassion. Creating such a space can help to lower the "affective filter," defined by Krashen and Terrell (1998) as a set of affective variables including learners' attitude, self-esteem, and level of anxiety that can act as a screen to prevent learning. Indigenous adults may have specific filters related to trauma caused by colonial history and contemporary realities (Jenni et al., 2017). Strategies to create a safe language learning environment include not putting 
students on the spot, not correcting speech or accent unless requested, using relevant and engaging materials, spending time outdoors, and the incorporation of fun and games (see ADULT LEARNERS; WHERE ARE YOUR KEYS).

Settler colonialism "is a distinct type of colonialism that functions through the replacement of Indigenous populations with an invasive settler society" (Bhambra, n.d., para. 1). In North America, this replacement began through violence and murder of the Indigenous population, then by appropriating lands through manipulative treaty processes, and then through harmful assimilation policies and practices that prevented maintenance of Indigenous languages and cultures such as residential schools. Foreign diseases also significantly reduced the populations of Indigenous Peoples in many places, including the pacific northwest coast of North America. The decimation of Indigenous Peoples, sometimes by 99 percent, aided settler colonialism, and contributed to language loss through the significant decline of speakers. Unlike some cases of colonialism where the foreign entity eventually leaves, settler colonialism continues to exist as long as settlers live on appropriated Indigenous land (see RESIDENTIAL SCHOOLS; THE INDIAN ACT).

Seven fluent first-language speakers of Skwwxwú7mesh Sníchim remained when the CSLP began in 2016. Today, sadly, there are none.

Seven thousand plus languages are spoken in the world today (Simons \& Fennig, 2018), but it is estimated that 50-90 percent of these languages will cease to be spoken in the next 100 years unless deliberate action is taken (Austin \& Sallabank, 2011). Before European contact, 
there were an estimated 450 Indigenous languages spoken in what is now Canada, but today only about 61 of these remain (Statistics Canada, 2015). There are 34 Indigenous languages spoken in British Columbia today; all have less than 800 fluent speakers, 23 have less than 100 speakers, and nine have less than 10 speakers, including Skwwxwú7mesh Sníchim (FPCC, 2018).

səliliwətał (Tsleil-Waututh) are an Indigenous People whose primary ancestral residences include communities along the eastern Burrard Inlet around present-day Belcarra, the mouth of the Indian Arm river, and around present-day Port Moody (see Figure 1). Before Europeans arrived, there were up to 30,000 səlilwətał people living throughout the territory, but the arrival of European diseases devastated the population. There were only an estimated nine səlilwətał people remaining by the mid-1800s (Morin, 2018). In 1871, the surviving səlilwətał relocated to the present-day Átsnach, one of the three reserve sites assigned to the səlilwətał people.

In 1923, the adult men and designated Indian Band chiefs of the neighbouring Skwwxwú7mesh reserves amalgamated under the Indian Act to form one Squamish Nation (Squamish Nation, 2013). The səlilwətał were invited but declined to join as they wanted to retain their identity as a distinct nation (Morin, 2015). However, following the decline of the səlilwətał population, significant intermarriage occurred between səlilwətał men and Skwwxwú7mesh women. As a result of multiple generations of intermarriage, many səlilwətał families became Skֵwxwú7mesh Sníchim speakers or bilingual speakers with Skֵwxwú7mesh 
Sníchim and həńq̇əmińəm (see SETTLER COLONIALISM; SKWXWÚ7MESH ÚXWUMIXW; THE INDIAN ACT; TSLEIL-WAUTUTH NATION).

Skwxwú7mesh is the name of the Squamish People and the Squamish River in Skwxwú7mesh Sníchim. There are many interpretations on the linguistic meaning of the name but no agreed upon translation. Before Europeans arrived, there were up to 90,000 Skwwxwú7mesh living throughout Skwwxwú7mesh territory, but the arrival of European diseases devastated the population. There were only an estimated 300-600 Sknwxwú7mesh remaining by the mid-1800s (Baker-Williams, 2006) (see SKWXWÚ7MESH TERRITORY; SKWXWÚ7MESH ÚXWUMIXW).

Skwwwú7mesh Sníchim is the name of the Squamish language in the Squamish language. It means Squamish language.

Skxwxwú7mesh Sníchim - Xwelíten Snichím Sknexwts is the first Squamish-English dictionary. It was edited by Peter Jacobs and Vanessa Campbell and includes input from dozens of speakers, texts, and conversations. It took 18 years to complete (Trigg, 2011).

Skwwxú 7 mesh Territory is 673,540 hectares that include the English Bay, Burrard Inlet, and Howe Sound watersheds (see Figure 1). The territory overlaps in many places with neighbouring Indigenous Peoples' territories. Skwwxwú7mesh Territory includes a number of historical villages currently unoccupied. Many of the language revitalization efforts with 
Skwwxwú7mesh Sníchim are taking place in the communities of Xwmelch'stn, Eslha7an, and St'a7mes.

Skwwxú7mesh Úxwumixw is the Skwwxwú7mesh name for the Squamish Nation. The 1876 Indian Act assigned the Skwxwú7mesh to 26 reserve sites that were located at historically occupied communities of related family groupings, but the government would later expropriate and partition additional lands without consent. In 1923, the adult men and designated Indian Band chiefs amalgamated under the Indian Act to form one Squamish Nation to better protect Skwxwú7mesh lands and interests (Squamish Nation, 2013). Today there are 4,080 Squamish Nation members (see FIRST NATION; SETTLER COLONIALISM; THE INDIAN ACT).

Slúlum are songs, an important part of Skwxwú7mesh culture and carriers of Skwwxwú7mesh language. Slúlum are used to teach language in the CSLP and DSLP.

Squamish is the English word for Skwxwú7mesh and is used for terms like Squamish language, Squamish peoples, and Squamish Nation in English. It is also the name of a town between Vancouver and Whistler. The majority of Skwwwú7mesh people do not live in the town of Squamish.

Squamish Nation (see SKWXWÚ7MESH ÚXWUMIXW). 
Squamish Nation Language and Culture Certificate was a post-secondary language certificate developed by the Squamish Nation through Capilano University and Nicola Valley Institute of Technology. Peter Jacobs and Vanessa Campbell taught all courses in the certificate. It was offered as a part-time program over five years in the 2010s.

Sxwexwiýám are Sknwxwú7mesh legends. Sxwwexwiýám were some of the first pieces of language to be recorded by early anthropologists and linguists, and they are an important source of linguistic information, oral literature, and cultural teachings. Sxwwexwiýám are used to teach language in the CSLP and DSLP.

$T$

Ta Nexwníwn ta a Ímats, Teachings for Your Grandchildren, was an Elders' group that formed in 1993 as an advisory group for Skwwwú7mesh Sníchim with the Squamish Nation Education Department. They were instrumental in documenting and revitalizing the language. Participants at different times included Chief Lawrence Baker, Barbara Charlie, Tina Cole, Nora Desmond, Hilda Duerden, Frank Guerrero, Ernie Harry, Lena Jacobs, Lila Johnston, Yvonne Joseph, Addie Kermeen, Eva Lewis, Margaret Locke, Frank Miranda, Valerie Moody, Stella Newman, Lucille Nicholson, Audrey Rivers, Alex Williams, and Doris Williams (Squamish Nation Education Department, 2011) (see LANGUAGE CHAMPIONS; TEACHERS).

Teachers, called Úsaylh or Nexwsúsaylh in Skwwxwú7mesh Sníchim, are those who actively work to pass on the language, whether or not they have formal training. Self-teaching, teaching one's children, and teaching others are all essential elements of language 
revitalization. Sknwxwú7mesh Sníchim has been taught formally since the 1960s (Squamish Nation Education Department, 2011). Since that time, the language has been taught in community classes, preschool, elementary and high schools, post-secondary programs, Mentor-Apprentice Programs, as well as in the homes of Skwxwú7mesh families. All of the teachers who have worked and continue to work in each of these capacities have been essential to the reclamation and revitalization of Skwwxwú7mesh Sníchim (see LANGUAGE CHAMPIONS).

The Certificate in Skxwxwú7mesh Language Proficiency (CSLP) began in 2016 as a program at Simon Fraser University (SFU) for young adults of Skwwxwú7mesh descent. Kwi Awt Stelmexw conceived of and developed the program and approached SFU about delivering it through SFU's Certificate in Indigenous Language Proficiency. SFU had created this certificate program for First Nations to offer credit for in-community Indigenous language courses. The CSLP would be the first time SFU would run the certificate as a fulltime immersion program. Students in the CSLP receive 900 hours of immersion instruction over the course of a school year. The CSLP is taught using primarily the Where Are Your Keys method, as well as Skwwxwú7mesh legends and songs. Most students reach an intermediate level of Skwwxú7mesh Sníchim by the end of the program (intermediate-low according to ACTFL scales). Students also earn a Certificate in Indigenous Language Proficiency, and the credits they earn can be used towards an undergraduate degree. The first two cohorts of the CSLP were taught by Khelsilem and met at SFU's downtown campus. Subsequent cohorts have been taught by previous graduates of the program, including Swo-wo Billy and Char George, meeting at various locations on Skwwxwú7mesh and səlilwətał lands. 
The Diploma in Sḱwxwú7mesh Language Proficiency (DSLP) began in 2018 as a partnership between the Squamish Nation and Simon Fraser University (SFU). The first cohort met one full day per week over the course of two years and graduated in the spring of 2020. The students were graduates from the CSLP and other programs such as the Squamish Nation Language and Culture Certificate. The instructors were Peter Jacobs and Vanessa Campbell.

In September 2020, the second offering of the Diploma program began, this time as a partnership between the Squamish Nation, Tsleil-Waututh Nation, Kwi Awt Stelmexw, and SFU. It is a full-time program in which students spend 450 hours in immersion over the course of one school year. Program participants are predominantly graduates from the CSLP. The Sknwxwú7mesh Sníchim instructors include Swo-wo Billy, Char George, Victoria Fraser, and Norman Guerrero. The students earn a Diploma in Indigenous Language Proficiency, and the credits they earn can be used towards an undergraduate degree.

The Indian Act of 1876 forced Indigenous Peoples onto reserves and gave the Canadian government control over all aspects of Indigenous Peoples' lives. The Act aimed at assimilating Indigenous Peoples, forbidding language use and cultural practices, requiring Indigenous children to attend residential schools, and imposing non-Indigenous governance structures (Henderson, 2018). Although many changes to the Indian Act have been made over time, removing the most discriminatory restrictions, the Act continues to exist and sets rules for Indigenous reserves, resources, and governance (see RESIDENTIAL SCHOOLS; SETTLER COLONIALISM; SəĹILWӘTA£; SKWXWÚ7MESH ÚXWUMIXW). 
The Indigenous Languages Act is legislation enacted by the Government of Canada in 2019. The Act affirms Aboriginal Rights within Section 35 of the Canadian Constitution and affirms its use to assist in the implementation of the UN Declaration on the Rights of Indigenous Peoples. It "establishes an independent Office of the Commissioner of Indigenous Languages that will champion and support language revitalization and review and report on Canada's compliance to its obligations under the Act" (Assembly of First Nations, 2019, p. 25). It also enables Indigenous communities to enter into agreements with governing bodies to facilitate its implementation. It is yet to be fully enacted, and there have been calls for a national strategy for ILR in Canada to support its implementation (Bliss et al., 2020).

The Truth and Reconciliation Commission of Canada (TRC) launched in 2008 with the purpose of documenting the history and impacts of residential schools on Indigenous Peoples in Canada (Truth and Reconciliation Commission of Canada, 2015). Through meetings held across the country with over 6,000 witnesses, the TRC gave residential school survivors an opportunity to share their stories in order to reveal the truth of Canada's abusive history, which had previously been hidden from the majority of Canadians. In 2015, the TRC published its findings along with 94 calls to action that include five calls regarding Indigenous language and culture (see RESIDENTIAL SCHOOLS; SETTLER COLONIALISM; THE INDIAN ACT).

The Yellow House is a yellow house in a residential area on Tsleil-Waututh Nation (TWN) land in North Vancouver that is used to house and support TWN language revitalization efforts. In 2019, the CSLP was invited to move into the house. The Certificate program staff, 
TWN staff, and team from Where Are Your Keys all worked out of the Yellow House mutually supporting each other in their efforts (see SəĹILWOTAE; TSLEIL-WAUTUTH NATION).

Tsleil-Waututh Nation (TWN) is the First Nations government of the səlilwətał. Today there are 540 TWN members. For many decades, TWN has been supporting efforts to revitalize the həńq́əmińəm language. Starting in 2018, TWN started funding efforts to revitalize Sknwxwú7mesh Sníchim as well. Many səlilwətał people are descendants of

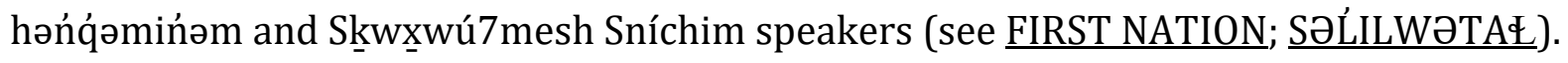

$\boldsymbol{U}$

Urbanization has meant that certain opportunities exist for Skֵwxwú7mesh and səlilwətał peoples. While the encroachment of the city originally devastated their populations and was one of the main causes of language decline, today it also means that reconciliation efforts by the cities and their institutions focus on working with these Nations. It also means that young people from these Nations are less likely than those from rural communities to move far from home in search of jobs and services.

\section{$\boldsymbol{V}$}

Vanessa Campbell (Iýál) has been involved in Skwwxwú7mesh language activism since 1972. She was one of Louis Miranda's first students and taught with him in the first high school Skwwxwú7mesh Sníchim courses. She has taught language classes at all levels for over 30 years, worked many years in the Squamish Nation Education Department, and co-edited the Squamish-English dictionary. She has also taught several young language learners, 
including Khelsilem, through an intensive Mentor-Apprentice Program, and has been teaching in the DSLP (see LANGUAGE CHAMPIONS; TEACHERS).

\section{$W$}

Where Are Your Keys (WAYK) was developed by Evan Gardner and is the primary immersion method used in the CSLP and the second offering of the DSLP. Where Are Your Keys is a series of game-like lessons that build on each other, relying on oral language and supported by several techniques including the use of American Sign Language. Participants move on to a new lesson once they have practiced the previous one. New students are then able, and encouraged, to lead more novice learners through the previous lesson almost immediately. By encouraging learners to quickly become teachers and through its engaging participant-led format, WAYK is not only an effective method for rapid language acquisition, but also facilitates community building and strengthening (Where Are Your Keys, 2021). Where Are Your Keys has been applied in several Indigenous language communities in North America (Gardner \& Ciotti, 2018) (see EVAN GARDNER; SAFE LEARNING ENVIRONMENTS; THE CERTIFICATE IN SKWXWÚ7MESH LANGUAGE PROFICIENCY).

\section{$\boldsymbol{X}$}

Xwmélch'stn' Estimiaw'txw, Capilano Little Ones School, opened in 2002 as a preschool with a goal to grow to a Sknwxwú7mesh immersion elementary school. Skwwwwú7mesh Sníchim is spoken and taught at the school, which now offers classes up to Grade 2. However, the immersion goal has not been attainable due to a lack of proficient adult speakers who can work as certified teachers (Baker-Williams, 2006) (see MISSING GENERATION). 
$\boldsymbol{Y}$

Yelxxtsán is a word created by participants of the CSLP that means "to language hunt." Language hunting is a WAYK technique in which a learner tries to identify or use new language through conversation with a more fluent speaker. When asked why he chose this term, WAYK founder Evan Gardner said, "if everyone hunted and ate whales, we would care a lot more about whales!" Mary Leighton (2017) elaborates: "When we start hunting for language, we start caring not just about the language, but also about the population of language speakers and the factors that support a healthy population of speakers. After all, we want to keep hunting language!" (para. 6). 


\section{About the Authors}

Nicki Benson is a PhD candidate in Indigenous Language Revitalization at the University of Victoria. Working with the Skxwxwú7mesh language community, her research explores success factors in adult immersion education for language revitalization. She has worked in language education for over 15 years as a teacher, researcher, and consultant.

Khelsilem is a Sknwwwú7mesh-Kwakwaka ${ }^{\prime}$ wakw educator and community leader. He is a second-language speaker of Skwwxwú7mesh Sníchim with eight years of experience teaching in community-based programs. His work focuses on the development of adult secondlanguage speakers with high degrees of proficiency to aid in the full recovery and vitality of Sknwxwú7mesh Sníchim. 


\section{References}

Assembly of First Nations. (2019). A guide to an act respecting Indigenous languages: A tool for First Nations language revitalization. https://www.afn.ca/wpcontent/uploads/2019/08/Respecting_Languages_Report_ENG.pdf

Austin, P. K., \& Sallabank, J. (Eds.). (2011). Cambridge handbook of endangered languages. Cambridge University Press.

Baker-Williams, K. (2006). Na mi k'anatsut ta Skwxwu7Mesh Snichim chet: Squamish language revitalization: From the hearts and the minds of the language speakers. https://open.library.ubc.ca/cIRcle/collections/ubctheses/831/items/1.0092805

Bhambra, G. K. (n.d.). Settler colonialism. Global social theory. https://globalsocialtheory.org/concepts/settler-colonialism/

Bliss, H., Gessner, S., Herbert, T., \& Parker, A. (2020). Framing the discussion: A proposal for a national strategy for the implementation of Bill C-91. https://fpcc.ca/wpcontent/uploads/2020/08/FPCC_national_strategy_discussion_paper_June_11_2020.p df

Caulley, D. N. (2008). Making qualitative research reports less boring: The techniques of writing creative nonfiction. Qualitative Inquiry, 14(3), 424-449.

Czaykowska-Higgins, E. (2009). Research models, community engagement, and linguistic fieldwork: Reflections on working within Canadian indigenous communities. Language Documentation \& Conservation, 3(1), 15-50.

First Peoples' Cultural Council (FPCC). (2014). Report of the status of B.C. First Nations languages (2nd ed.). http://www.fpcc.ca/files/PDF/Language/FPCC-LanguageReport141016-WEB.pdf

First Peoples' Cultural Council (FPCC). (2018). Report of the status of B.C. First Nations languages (3rd ed.). http://www.fpcc.ca/files/PDF/FPCC-LanguageReport-180716WEB.pdf

First Peoples' Cultural Council (FPCC). (2019). Mentor-Apprentice Programs. http://www.fpcc.ca/language/Programs/Master-Apprentice.aspx

Fishman, J. (2001). Why is it so hard to save a threatened language. In J. Fishman (Ed.), Can threatened languages be saved? (pp. 1-23). Multilingual Matters.

Fishman, J. A. (1991). Reversing language shift: Theoretical and empirical foundations of assistance to threatened languages. Multilingual Matters. 
Gardner, E., \& Ciotti, S. (2018). An overview of Where Are Your Keys? In L. Hinton, L. Huss, \& G. Roche (Eds.), The Routledge handbook of language revitalization (pp. 137-145). Routledge.

Gerdts, D. (2017). Indigenous linguists: Bringing research into language revitalization. International Journal of American Linguistics, 83(4), 607-617.

Grenoble, L. A., \& Whaley, L. J. (2006). Saving languages: An introduction to language revitalization. Cambridge University Press.

Griffiths, C., \& Soruc, A. (2018). Learning as an adult. In A. Burns \& J. C. Richards (Eds.), The Cambridge guide to learning English as a second language (pp. 27-34). The University of Cambridge.

Henderson, W. (2018). Indian Act. In The Canadian Encyclopedia. https://www.thecanadianencyclopedia.ca/en/article/indian-act

Hinton, L. (1994). Flutes of fire: Essays on California Indian languages. Heyday Books.

Hinton, L. (2011). Language revitalization and language pedagogy: New teaching and learning strategies. Language and Education, 25(4), 307-318.

Hinton, L., Huss, L., \& Roche, G. (2018). The Routledge handbook of language revitalization. Routledge.

Hurren, W. (2014). Mapwork: Atlas interrupted. In A. D. Reid, E. P. Hart, \& M. A. Peters (Eds.), A Companion to research in education. https://doi.org/10.1007/978-94-0076809-3_69

Hurren, W. (2018). Call it by its name: A partial glossary about sexual harassment for faculty. The McGill Journal of Education, 53, 629-645.

Indigenous Foundations. (2009). The residential school system. https://indigenousfoundations.arts.ubc.ca/the_residential_school_system/

International Labour Organization. (1989). Indigenous and tribal peoples convention. https://www.ilo.org/dyn/normlex/en/f?p=NORMLEXPUB:12100:0::NO::P12100_ILO_ CODE:C169

Jenni, B., Anisman, A., McIvor, O., \& Jacobs, P. (2017). An exploration of the effects of mentor-apprentice programs on mentors' and apprentices' wellbeing. International Journal of Indigenous Health, 12(2), 25-42. 
Kell, S. (2014). Polysynthetic language structures and their role in pedagogy and curriculum for BC Indigenous languages: Final report. https://www2.gov.bc.ca/assets/gov/education/administration/kindergarten-tograde-12/indigenous-education/research/polysynthetic_language.pdf

King, J. (2001). Te Kohanga Reo: Māori language revitalization. In L. Hinton \& K. Hale (Eds.), The green book of language revitalization in practice (pp. 119-128). Academic Press.

Krashen, S. D., \& Terrell, T. D. (1998). The natural approach: Language acquisition in the classroom. Prentice Hall.

Leighton, M. (2017). Why do we "hunt" language? Where Are Your Keys. https://whereareyourkeys.org/why-do-we-hunt-language/

Leonard, W. Y., \& Haynes, E. (2010). Making "collaboration" collaborative: An examination of perspectives that frame linguistic field research. Language Documentation and Conservation, 4, 269-263.

McCarty, T. L. (2012). Indigenous language revitalization. In J. Banks (Ed.), Encyclopedia of diversity in education (pp. 1172-1176). SAGE Publications.

McIvor, O. (2015). Adult Indigenous language learning in Western Canada: What is holding us back? In K. Michel, P. Walton, E. Bourassa, \& J. Miller (Eds.), Our living languages: Papers from the 19th Stabilizing Indigenous Languages Symposium (pp. 37-49). Linus Learning.

McIvor, O., \& Anisman, A. (2018). Keeping our languages alive: Strategies for Indigenous language revitalization and maintenance. In Y. Watanabe (Ed.), Handbook of cultural security (pp. 90-109). https://doi.org/10.4337/9781786437747.00011

McIvor, O., \& Jacobs, P. (2016). NETOLNEW language learning assessment tool (v3.1). https://netolnew.ca/assessment/

Miller, B., \& Paola, S. (2019). Tell it slant: Writing and shaping creative nonfiction (3rd ed.). McGraw-Hill.

Morin, R. (2018). Discovering new pathways to old teachings: The Paul Creek method for second language acquisition for adult Cree language learners. https://dspace.library.uvic.ca/handle/1828/10017

Muñoz, C., \& Singleton, D. (2011). A critical review of age-related research on L2 ultimate attainment. Language Teaching, 44(1), 1-35.

Pine, A., \& Turin, M. (2017). Language revitalization. In Oxford Encyclopedia of Linguistics. https://doi.org/10.1093/acrefore/9780199384655.013.8 
Rice, K. (2009). Must there be two solitudes? Language activists and linguists working together. In J. Reyhner \& L. Lockard (Eds.), Indigenous language revitalization: Encouragement, guidance and lessons learned (pp. 37-59). Northern Arizona University.

Richardson, L., \& St. Pierre, E. (2018). Writing: A method of inquiry. In N. Denzin \& Y. Lincoln (Eds.), The SAGE handbook of qualitative research (5th ed., pp. 818-838). SAGE Publications, Inc.

Rosborough, T., Rorick, C. L., \& Urbanczyk, S. (2017). Beautiful words: Enriching and indigenizing Kwak'wala revitalization through understandings of linguistic structure. Canadian Modern Language Review, 73(4). https://doi.org/10.3138/cmlr.4059

Simons, G. F., \& Fennig, C. D. (2018). Ethnologue: Languages of the world. https://www.ethnologue.com

Squamish Nation. (2013). Our history. http://www.squamish.net/about-us/our-history/

Squamish Nation Education Department. (2011). Skwxwú7mesh Sníchim - Xwelíten Sníchim Skexwts. University of Washington Press.

Statistics Canada. (2015). Aboriginal languages in Canada. https://www12.statcan.gc.ca/census-recensement/2011/as-sa/98-314-x/98-314x2011003_3-eng.cfm

Tedick, D. J., Christian, D., \& Fortune, T. W. (2011). The future of immersion education: An invitation to "dwell in possibility." In Immersion education: Practices, policies, possibilities. https://doi.org/10.21832/9781847694041-004

Trigg, N. (2011, May 20). A great collection of words: First-ever Squamish-English dictionary part of multi-faceted strategy to boost "endangered" tongue. The Squamish Chief. https://www.squamishchief.com/community/a-great-collection-of-words1.1105262

Truth and Reconciliation Commission of Canada. (2015). Honouring the truth, reconciling for the future: Summary of the final report of the Truth and Reconciliation Commission of Canada.

http://www.trc.ca/assets/pdf/Honouring_the_Truth_Reconciling_for_the_Future_July_ 23_2015.pdf

Tuck, E., \& Ree, C. (2013). A glossary of haunting. In S. Holman Jones, T. E. Adams, \& C. Ellis (Eds.), Handbook of autoethnography (pp. 639-658).

University of British Columbia. (n.d.). "Uncle” Louis Miranda. http://chroniclesofpride.ikebarberlearningcentre.ubc.ca/uncle-louis-miranda.html 
Where Are Your Keys. (2021). Our purpose. https://whereareyourkeys.org/fluencymanifesto/ 